\title{
SOCIAL MEDIA ENGAGEMENT SEBAGAI MEDIATOR ANTARA FEAR OF MISSING OUT DENGAN KECANDUAN MEDIA SOSIAL PADA REMAJA
}

\author{
Sarentya Fathadhika dan Afriani \\ Program Studi Psikologi, Fakultas Kedokteran, Universitas Syiah Kuala \\ E-mail: sfathadhika@yahoo.com
}

\begin{abstract}
ABSTRAK. Fear of missing out atau kekhawatiran akan kehilangan momen penting pada aktivitas media sosial menjadi salah satu faktor yang menyebabkan tingginya intensitas remaja dalam menggunakan media sosial saat ini. Hal tersebut dapat mengarah kepada terjadinya kecanduan media sosial. Penelitian ini bertujuan untuk mengetahui hubungan antara fear of missing out dengan kecanduan media sosial yang dimediasi oleh social media engagement pada remaja di Kota Banda Aceh. Sejumlah 343 remaja dengan rentang usia 13 - 18 tahun dari empat sekolah menengah di Kota Banda Aceh terpilih sebagai subjek penelitian melalui metode multistage cluster dan disproportionate stratified random sampling. Penelitian ini mengadaptasi alat ukur Social Media Disorder (SMD) scale-short version dari Eijnden, Lemmens, dan Valkenburg untuk mengukur variabel kecanduan media sosial, Fear of Missing Out Scale dari Przybylski, Murayama, Haan, dan Gladwell untuk variabel fear of missing out, dan Social Media Engagement Questionnaire dari Przybylski, Murayama, Haan, dan Gladwell untuk variabel social media engagement. Data penelitian dianalisa menggunakan metode bootstrap untuk menguji hipotesa penelitian. Hasil analisa menunjukkan bahwa fear of missing out memiliki hubungan yang signifikan secara langsung $(\beta=0,08 ; \mathrm{p}<0,05)$ dan tidak langsung $(\beta=0,10 ; \mathrm{p}<0,05)$ terhadap kecanduan media sosial. Penelitian ini menunjukkan bahwa risiko kecanduan media sosial berkaitan dengan fear of missing out yang dimediasi oleh social media engagement. Semakin besar kekhawatiran remaja akan kehilangan momen dalam media sosial, maka mendorong mereka untuk terus dapat terikat dengan aktivitas di media sosial yang mengarah kepada perilaku kecanduan.
\end{abstract}

Kata kunci: kecanduan media sosial; fear of missing out; social media engagement; remaja

\section{SOCIAL MEDIA ENGAGEMENTAS MEDIATOR BETWEEN FEAR OF MISSING OUT AND SOCIAL MEDIA ADDICTION AMONG ADOLESCENTS}

\begin{abstract}
Fear of missing out or fear about losing important moments on social media activities is one of factors that lead to the high intensity of adolescents using social media in the recent years. It can lead to social media addiction. This study aimed to determine the relationship between fear of missing out and social media addiction mediated by social media engagement among adolescents in Banda Aceh. A total of 343 adolescents (13 to 18 years old) from four high schools in Banda Aceh were selected using multistage cluster and disproportionate stratified random sampling. This study using adapted Social Media Disorder (SMD) Scale-short version by Eijnden, Lemmens, and Valkenburg to measure social media addiction, Fear of Missing Out Scale by Przybylski, Murayama, Haan, and Gladwell for fear of missing out variable, and Social Media Engagement Questionnaire by Przybylski, Murayama, Haan, and Gladwell for social media engagement variable. Data were analyzed using bootstrap method to test the research hypothesis. Results of the study showed that the fear of missing out had significant direct $(\beta=0,08 ; p<0,05)$ and indirect $(\beta=0,10 ; p<0,05)$ relationships to social media addiction. This study indicated that social media addiction is related to fear of missing out and mediated by social media engagement. It means that higher fear of missing out lead to social media engagement then will effect to social media addiction.
\end{abstract}

Keywords: Social Media Addiction; Fear of missing out; Social Media Engagement; Adolescent

\section{PENDAHULUAN}

Media sosial merupakan salah satu alat komunikasi yang paling banyak digunakan saat ini dan kalangan remaja menjadi pengguna terbesar di Indonesia. Salah satu alasan remaja saat ini menjadi mayoritas pengguna media sosial adalah mereka lahir dan tumbuh saat era informasi dan digital berkembang pesat (Sugiharto, 2016). Oleh karena itu, penerimaan serta literasi terhadap media sosial pada usia remaja lebih mudah dibandingkan kelompok usia lain (Sugiharto, 2016). Hurlock (2009) menyebutkan bahwa masa remaja dibagi menjadi dua bagian, yaitu remaja awal dengan usia 13-16 atau 17 tahun dan remaja akhir dengan usia 16 atau 17 tahun sampai 18 tahun. Ditinjau dari manfaatnya, penggunaan media sosial pada remaja berkaitan dengan tugas perkembangan yaitu pembentukan identitas diri (Hurlock, 2009; Saphiro \& Margolin, 2014). Manfaat lain dari penggunaan media sosial bagi remaja yaitu untuk sarana komunikasi antar remaja, mendapatkan dukungan dari remaja lainnya, serta mendapatkan saran dan informasi terkait dengan tujuan karir (Siddiqui \& Singh, 2016).

Sebaliknya, media sosial juga dapat berdampak negatif terhadap psikologis remaja, khususnya menghasilkan pola perilaku bermasalah, seperti penggunaan media sosial yang berlebihan (Al-Menayes, 2015). Hal tersebut dikarenakan pada usia tersebut, remaja belum terlalu berpengalaman dan memiliki keterbatasan dalam pengaturan diri (O'Keeffe \& Pearson, 2011). Oleh karena itu, penggunaan media sosial dapat mengarah kepada perilaku kecanduan media sosial (Kirik, Arslan, Cetinkaya, \& Gul, 2015). 
Menurut Eijnden, Lemmens, dan Valkenburg (2016), kecanduan media sosial merupakan suatu gangguan perilaku dalam penggunaan media sosial secara berlebihan dan mengarah kepada kecenderungan untuk terus menerus menggunakan media sosial. Eijnden, dkk., (2016) mengungkapkan bahwa individu dapat dikatakan mengalami kecanduan media sosial jika memiliki lima atau lebih dari sembilan kriteria yaitu: 1) preoccupation yang ditandai dengan mengabaikan segala sesuatu hal saat menggunakan media sosialdan menghabiskan banyak waktu untuk memikirkan atau berkhayal tentang media sosial selama tidak menggunakan media sosial; 2) tolerance yang ditandai dengan meningkatnya jumlah waktu yang dihabiskan di media sosial untuk merasakan efek yang diinginkan, seperti kegembiraan dan kepuasan; 3) withdrawal yang ditandai dengan munculnya perasaan gelisah, jengkel, marah, frustasi, cemas, atau sedih saat tidak dapat menggunakan atau mencoba mengurangi atau menghentikan penggunaan media sosial; 4) persistence yang ditandai dengan adanya hasrat abadi untuk terus menggunakan media sosial atau usaha yang gagal untuk menghentikan, mengendalikan, atau mengurangi penggunaan media sosial; 5) escape yang ditandai dengan keterlibatan pengguna pada penggunaan media sosial untuk melepaskan diri atau menghilangkan keadaan mood negatif, seperti ketidakberdayaan, rasa bersalah, kegelisahan, atau depresi; 6) problems yang ditandai dengan perilaku yang terus menggunakan media sosial meskipun menyadari konsekuensi negatif dari perilaku tersebut terhadap kehidupan; 7) deception yang ditandai dengan perilaku berbohong atau menutupi kepada individu lain tentang sejauh mana individu menggunakan media sosial; 8) displacement yang ditandai dengan perilaku penggunaan media sosial yang mendominasi sehingga menyebabkan berkurangnya aktivitas sosial dan rekreasi lainnya; dan 9) conflict yang ditandai dengan munculnya masalah yang lebih substansial seperti hampir kehilangan, misalnya kehilangan hubungan atau kesempatan penting yang berkaitan dengan sekolah atau pekerjaan sebagai akibat dari penggunaan media sosial.

Salah satu bentuk perilaku kecanduan media sosial dapat ditunjukkan dengan banyaknya jumlah waktu dalam menggunakan media sosial, misalnya memeriksa profil Facebook secara berulang hanya untuk melihat sekilas jumlah suka dari pengguna lain (Al-Menayes, 2015). Hasil penelitian lima mahasiswa Fakultas Keperawatan Universitas Airlangga menunjukkan bahwa 83\% remaja tidak dapat melepaskan diri dari media sosial meskipun dalam sehari (Tim Pekan Kreativitas Mahasiswa Sosial Humaniora, 2016). Selanjutnya, sebuah survei internasional pada tahun 2016 menunjukkan bahwa sebanyak $50 \%$ remaja merasa mengalami kecanduan media sosial (Common Sense Media, 2016). Berdasarkan survei tersebut diketahui sebanyak 78\% remaja mengecek telepon genggamnya setiap satu jam sekali. Selain itu, sebanyak $72 \%$ remaja merasa perlu untuk membalas pesan melalui jaringan sosial dan pemberitahuan lainnya. Adanya kasus secara nasional dan internasional dengan nilai persen yang tinggi menunjukkan bahwa kecanduan media sosial pada remaja merupakan permasalahan global saat ini.

Salah satu hal yang dapat menyebabkan remaja mengalami kecanduan media sosial adalah fear of missing out (FoMO). Istilah FoMO pertama kali digunakan pada tahun 2013 di dalam sebuah penelitian ilmiah yang dilakukan oleh Przybylski, Murayama, DeHaan, dan Gladwell (2013). Przybylski, dkk., (2013) mendefinisikan FoMO sebagai kekhawatiran yang dialami individu ketika orang lain memiliki pengalaman yang mengesankan di saat ketidakhadiran dirinya. Individu yang mengalami FoMO memiliki keinginan untuk mengetahui segala sesuatu yang terjadi di lingkungan (Song, Zhang, Zhao, \& Song, 2017). Hal tersebut mendorong individu untuk terus menerus mempertahankan aktivitas di media sosial tanpa batasan waktu sehingga dapat mengarah kepada kecanduan media sosial (Abel, Buff, \& Burr, 2016).

Przybylski, dkk., (2013) menyebutkan bahwa FoMO hanya memiliki satu dimensi yaitu suatu keadaan yang menggambarkan perasaan ketakutan, kekhawatiran, dan kecemasan yang dimiliki individu disaat ketidakhadiran dirinya dalam suatu kejadian, pengalaman, dan percakapan yang terjadi di lingkungan sosial yang luas (Przybylski, dkk., 2013). Selain itu, FoMO dapat dipahami sebagai rendahnya tingkat kebutuhan psikologi dasar (kompetensi, autonomi, dan keterhubungan dengan individu lain) (Self Determination Theory; Deci \& Ryan, 2008) yang disebabkan oleh tidak terpenuhinya pemenuhan kebutuhan psikologis. Individu yang memiliki tingkat kepuasan akan kebutuhan dasar yang rendah lebih tertarik untuk menggunakan media sosial (Przybylski, dkk., 2013).

Kaitan FoMO dengan kecanduan media sosial dapat dilihat dari peran media sosial terhadap individu yang mengalami FoMO. Kebutuhan dan dorongan yang muncul akibat FoMO dalam mempertahankan komunikasi dapat terpenuhi melalui media sosial (Abel, dkk., 2016). Tersedianya informasi dari media sosial memungkinkan individu untuk mengetahui peristiwa apa saja yang dilakukan orang lain sepanjang waktu. Hal tersebut menyebabkan individu yang mengalami FoMO dapat mengarah kepada kecanduan media sosial (Abel, dkk., 2016).

Adanya keterhubungan antara FoMO dengan kecanduan media sosial tidak terlepas dari intensitas penggunaan media sosial atau social media engagement (Przybylski, dkk., 2013). Hal tersebut menunjukkan bahwa hadirnya FoMO menyebabkan tingginya intensitas penggunaan media sosial yang menjadi indikasi perilaku kecanduan media sosial. Tingginya intensitas penggunaan media sosial menunjukkan tingkat social media engagement yang tinggi pula (Przybylski, dkk., 2013). Przybylski, dkk., (2013) mendefinisikan social media engagement sebagai intensitas partisipasi individu dalam penggunaan media sosial. Menurut McCay-Peet dan Quan-Haase (2016), social media engagement merupakan kualitas pengalaman 
yang didapatkan pengguna dari teknologi berbasis web yang memungkinkan pengguna berinteraksi, membuat, dan berbagi konten dengan individu dan organisasi di jaringan sosial. Terdapat enam model social media engagement (McCay-Peet \& Quan-Haase, 2016). Gambaran dari keenam model tersebut dapat dilihat di Gambar 1.

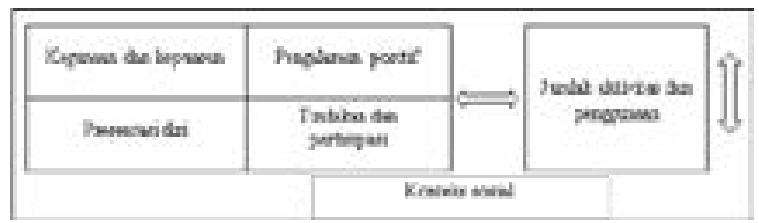

Gambar 1. Model social media engagement (McCay-Peet \& Quan-Haase, 2016)

Berdasarkan skema di atas dapat dipahami bahwa kegunaan dan kepuasan, pengalaman positif, presentasi diri, serta tindakan dan partisipasi terhadap media sosial saling berpengaruh terhadap rendah atau tingginya jumlah aktivitas dan penggunaan pada media sosial di dalam konteks sosial (McCay-Peet \& Quan-Haase, 2016). Dengan demikian, dapat dipahami bahwa social media engagement dapat dilihat dari tinggi atau rendahnya jumlah aktivitas dan penggunaan media sosial.

Individu dengan social media engagement yang tinggi akan menyebabkan permasalahan yang mengarah kepada perilaku maladaptif (Turel \& Serenko, 2012). Lebih lanjut, Ang (2017) menyebutkan bahwa semakin tinggi tingkat social media engagement pada remaja akan menyebabkan risiko yang lebih tinggi terhadap dampak negatif yang ditimbulkan. Dampak negatif yang mungkin ditimbulkan berupa perilaku yang maladaptif atau kecanduan terhadap internet dan aplikasi berbasis internet seperti media sosial (Brand, Laier, \& Young, 2014).

Munculnya social media engagement yang tinggi pada remaja dapat disebabkan oleh FoMO. Hal ini diungkapkan oleh Przybylski, dkk., (2013) bahwa individu yang mengalami FoMO memungkinkan dirinya terikat dengan media sosial. Karakteristik individu yang mengalami FoMO yaitu adanya dorongan untuk terus menggunakan media sosial (Przybylski, dkk., 2013).

Adanya keinginan untuk dapat mengikuti setiap peristiwa di dunia sosial membuat individu mempertahankan aktivitas di media sosial secara terus menerus (Shapiro \& Margolin, 2014). Hal tersebut menyebabkan intensitas penggunaan media sosial menjadi meningkat (Przybylski, dkk., 2013). Tingginya intensitas dalam menggunakan media sosial dapat menjadi indikasi perilaku kecanduan media sosial (Abel, dkk., 2016). Hal senada didukung oleh hasil penelitian Wegmann, Stodt, Brand, dan Chamarro (2017) yang mengemukakan bahwa keinginan untuk terus menggunakan media sosial yang disebabkan oleh FoMO menyebabkan tingginya intensitas penggunaan media sosial sehingga mengarah kepada kecanduan media sosial.

Beberapa perilaku social media engagement yang dimunculkan akibat FoMO, seperti remaja, merasa memiliki kebutuhan yang tinggi untuk menggunakan media sosial (Beyens, Frison, \& Eggermont, 2016), menggunakan media sosial pada waktu malam hari (Oshima, Nishida, Shimodera, Tochigi, Ando, \& Yamasaki, 2012; Van den Bulck, 2007), bahkan remaja meletakkan mobile phone-nya di bawah bantal untuk menghindari adanya pesan yang terlewatkan saat tengah malam (Lenhart, Ling, Campbell, \& Purcell, 2010), dan melewatkan waktu makan atau mempercepat durasi makan agar dapat terhubung dengan teman-temannya melalui media sosial (Van den Bulck \& Eggermont, 2006).

Berdasarkan pemaparan di atas dapat disimpulkan bahwa individu yang mengalami FoMO memiliki dorongan untuk menggunakan media sosial dalam memenuhi kebutuhan dasarnya. Hal ini dikemukakan oleh Wegmann, dkk., (2017) bahwa pengguna media sosial menggunakan media sosial untuk memenuhi dorongan dan kebutuhan di dalam dirinya. Penggunaan tersebut dapat memberikan kesenangan dan mencegah munculnya emosi negatif (Przybylski, dkk., 2013). Oleh karena itu, penggunaan media sosial dianggap sebagai wadah untuk mendapat-kan pengalaman positif dan menghindar dari masalah (Wegmann, dkk., 2017).

Terbukanya akses untuk tetap terhubung dan berinteraksi dengan individu lain dimana pun dan kapan pun menyebabkan tingginya engagement individu terhadap media sosial (Choi, Kim, Choi, Song, Kim, \& Youn, 2015). Individu dengan tingkat social media engagement yang tinggi ditandai dengan tingginya intensitas penggunaan media sosial (Przybylski, dkk., 2013). Hal tersebut yang kemudian memungkinkan individu mengalami kecanduan media sosial (Al-Menayes, 2015).

Penjelasan di atas menunjukkan bahwa individu yang mengalami FoMO dapat menyebabkan kecanduan media sosial jika memiliki tingkat social media engagement yang tinggi. Kekhawatiran akan ketinggalan informasi kemudian menyebabkan individu menggunakan media sosial dengan intensitas yang tinggi sehingga mengarahkannya kepada kecanduan media sosial. Oleh karena itu, beberapa hasil penelitian sebelumnya akan dijadikan landasan bagi peneliti untuk melakukan penelitian lebih lanjut dengan hipotesis penelitian yaitu adanya hubung-an antara FoMO dengan kecanduan media sosial yang dimediasi oleh social media engagement pada remaja di Kota Banda Aceh. Selain itu, terbatasnya penelitian serupa yang terpublikasi secara nasional, khususnya Kota Banda Aceh, yang mengkaji variabel fear of missing out, social media engagement, dan variabel kecanduan media sosial secara bersamaan membuat penelitian ini penting untuk dilakukan.

\section{METODE}

Penelitian ini menggunakan pendekatan kuantitatif dengan metode penelitian korelasi. Sebanyak 343 remaja berusia 13 sampai 18 tahun di Kota Banda Aceh terpilih menjadi subjek penelitian melalui metode multistage cluster sampling yaitu dengan menarik undian sehingga terpilih satu kecamatan dari sembilan kecamatan di Kota Banda Aceh yakni Kecamatan Kuta Alam. Terdapat sembilan Sekolah Menengah Pertama (SMP) Se-derajat di Kecamatan Kuta Alam dan terpilih dua sekolah yaitu SMPN 2 Banda Aceh dan SMPN 18 Banda Aceh serta dari sepuluh Sekolah Menengah Atas (SMA) Se-derajat terpilih SMAN 4 DKI 
Jakarta Banda Aceh, dan SMAN 8 Banda Aceh(Badan Pusat Statistik Kota Banda Aceh, 2018). Selanjutnya, pada masing-masing sekolah dipilih satu kelas dari masing-masing tingkatan yaitu kelas I, kelas II, dan kelas III. Penentuan jumlah sampel pada masing-masing kelas menggunakan teknik disproportionate stratified random sampling sehingga tanpa mengetahui jumlah populasi pada masing-masing kelas, peneliti menentukan jumlah sampel sebanyak 33 siswa pada setiap kelas. Setelah menentukan sampel penelitian diperoleh sebaran sampel seperti ditampilkan di Gambar 2.

\section{Metode Pengumpulan Data}

Alat ukur yang digunakan pada variabel kecanduan media sosial yaitu Social Media Disorder (SMD) Scale short version (Ejinden, dkk., 2016) yang terdiri dari sembilan kriteria yaitu preoccupation, tolerance, withdrawal, persistence, escape, problems, deception, displacement, dan conflict dengan pilihan jawaban dikotomos (ya atau tidak). Perolehan jawaban "ya" pada lima atau lebih butir aitem menunjukkan bahwa individu tersebut mengalami kecanduan media sosial. Sebaliknya, jika perolehan jawaban "ya" kurang dari lima butir aitem maka individu tersebut tidak mengalami kecanduan media sosial.

Variabel fear of missing out diukur dengan menggunakan Fear of Missing Out Scale (Przbylski, dkk., 2013) dengan unidimensi terdiri dari 10 item yang memiliki 5 pilihan jawaban (skala likert). Perolehan skor dari skala tersebut menunjukkan bahwa semakin tinggi skor yang diperoleh, maka akan semakin tinggi tingkat fear of missing out di dalam diri individu. Sebaliknya, semakin rendah skor yang diperoleh maka akan semakin rendah tingkat fear of missing out individu tersebut. Fear of Missing Out Scale memiliki tiga kategori tingkatan yaitu tingkat rendah, sedang, dan tinggi.

Variabel social media engagement diukur dengan menggunakan Social Media Engagement Questionnaire (Przbylski, dkk., 2013) dengan unidimensi terdiri dari 5 item dengan 8 pilihan jawaban (skala likert). Perolehan skor dari skala tersebut menunjukkan bahwa semakin

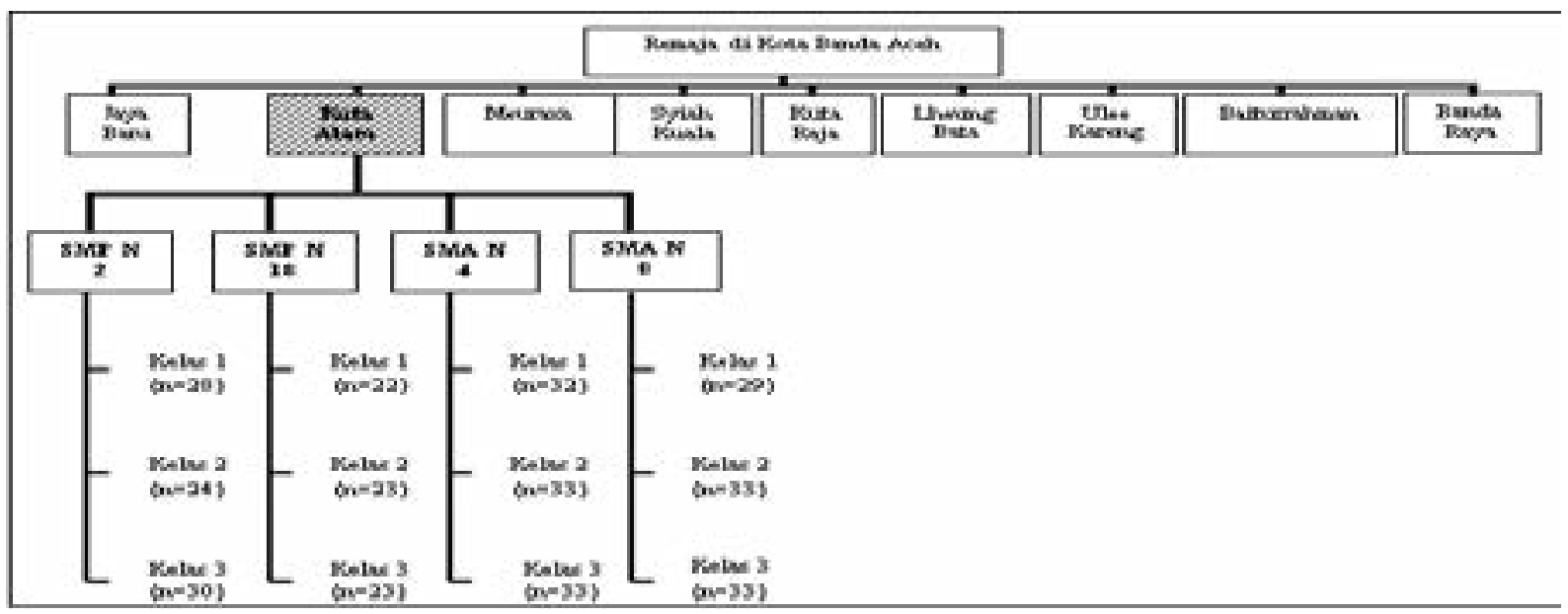

Gambar 2. Sebaran Sampel Penelitian

Tabel 1. Data Demografi Sampel Penelitian

\begin{tabular}{|c|c|c|c|}
\hline Deskripsi & Jumlah Subjek & Persentase $(\%)$ & Total $(\%)$ \\
\hline \multicolumn{4}{|l|}{ Jenis Kelamin } \\
\hline Laki-Laki & 104 & 30,3 & \multirow[t]{2}{*}{100} \\
\hline Perempuan & 239 & 69,7 & \\
\hline \multicolumn{4}{|l|}{ Usia } \\
\hline $13-15$ tahun & 164 & 47,8 & \multirow{2}{*}{100} \\
\hline $16-18$ tahun & 179 & 52,2 & \\
\hline \multicolumn{4}{|l|}{ Tingkat Pendidikan } \\
\hline SMP & 150 & 43,7 & \multirow{2}{*}{100} \\
\hline SMA & 193 & 56,3 & \\
\hline \multicolumn{4}{|l|}{ Asal Sekolah } \\
\hline SMPN 2 Banda Aceh & 82 & 23,9 & \multirow{4}{*}{100} \\
\hline SMPN 18 Banda Aceh & 68 & 19,8 & \\
\hline SMAN 4 DKI Jakarta Banda Aceh & 98 & 28,6 & \\
\hline SMAN 8 Banda Aceh & 95 & 27,7 & \\
\hline \multicolumn{4}{|l|}{ Jumlah Media Sosial yang Digunakan } \\
\hline $1-3$ & 250 & 72,9 & \multirow{3}{*}{100} \\
\hline $4-6$ & 84 & 24,5 & \\
\hline $7-9$ & 9 & 2,6 & \\
\hline
\end{tabular}


tinggi skor yang diperoleh, maka akan semakin tinggi tingkat social media engagement di dalam diri individu. Sebaliknya, semakin rendah skor yang diperoleh maka akan semakin rendah tingkat social media engagement atau tidak menunjukkan engagement terhadap media sosial pada individu tersebut.

Ketiga skala tersebut merupakan alat ukur yang disusun dalam bahasa Inggris, sedangkan sampel pada penelitian menggunakan bahasa Indonesia. Karena adanya perbedaan bahasa maka skala perlu diterjemahkan terlebih dahulu dalam versi bahasa Indonesia (forward translation) pada setiap butir pernyataannya. Selanjutnya, dilakukan penerjemahan kembali ke dalam versi bahasa Inggris (backward translation) untuk melihat keakuratan dan kejelasan dari butir pernyataan dari ketiga skala tersebut. Validitas ini diestimasi melalui pengujian terhadap kelayakan atau relevansi isi tes melalui analisis rasional oleh panel yang berkompeten atau melalui $e x$ pert judgment untuk melihat keakuratan setiap pernyataan yang diterjemahkan dari skala versi bahasa Inggris agar sesuai dengan variabel yang ingin diukur, kesesuaian pernyataan dengan konstrak, relevansi, tingkat kepentingan, kejelasan dan bias, sehingga pernyataan-pernyataan yang dikembangkan dalam skala sesuai dengan variabel atau konstrak psikologis yang ingin diukur (Azwar, 2013). Proses expert judgment melibatkan tiga orang reviewer yaitu dosen yang sesuai dengan ranah penelitian.

Pengembangan Social Media Disorder (SMD) Scale-short version yang dilakukan oleh Eijnden, dkk., (2016) memiliki nilai reliabilitas 0,82. Reliabilitas Social Media Disorder Scale yang telah diadaptasi ke dalam bahasa Turki bernilai 0,76 (Tas, 2017) dan bernilai 0,78 pada penelitian Savci dan Aysan (2017). Sementara pengembangan Fear of Missing Out Scale oleh Przybylski, dkk., (2013) dengan melakukan tiga kali penelitian memeroleh nilai reliabilitas yang sangat baik, yaitu 0,87, 0,90, dan 0,89. Fear of Missing Out Scale juga telah diadaptasi ke dalam bahasa Arab dengan nilai reliabilitas 0,82 (AlMenayes, 2016) dan bahasa Turki dengan nilai reliabilitas 0,81 (GÖkler, dkk., 2016). Selanjutnya, Social Media Engagement Questionnaire memiliki nilai reliabilitas antara 0,82 sampai 0,89 (Przybylski, dkk., 2013). Social Media Engagement Questionnaire telah digunakan pada penelitian lain seperti penelitian Al-Menayes (2015) dengan nilai reliabilitas 0,81 . Reliabilitas masing-masing skala pada penelitian ini yaitu 0,67 pada Social Media Disorder (SMD) Scale-short version, 0,74 pada Fear of Missing Out Scale, dan 0,72 pada Social Media Engagement Questionnaire.

\section{Metode Analisis Data}

Metode analisis data yang digunakan yaitu metode bootstrapping dengan bantuan Statistical Product and Service Solution (SPSS) ver. 21.0 for Windows dengan menggunakan PROCESS v3.0. Pada penelitian ini, metode bootstrapping dilakukan untuk menguji apakah hubungan antara FoMO dengan kecanduan media so- sial dimediasi oleh social media engagement. Melalui metode bootstrapping akan menguji hubungan langsung antara FoMO dengan kecanduan media sosial serta hubungan tidak langsung antara FoMO dengan kecanduan media sosial melalui social media engagement. Menurut Hayes (2013), jika rentang antara BootLLCI dan BootULCI yang diperoleh tidak mencakup nilai nol (0), maka dapat disimpulkan estimasi signifikan dan terjadi efek mediasi.

\section{HASIL DAN PEMBAHASAN}

Pada penelitian ini ditemukan sebanyak 98 (28,6\%) dari 343 subjek mengalami kecanduan media sosial. Sebagai tambahan, pada skala kecanduan media sosial menunjukkan sebagian besar remaja mengalami kesulitan untuk memikirkan sesuatu jika dilepaskan dari penggunaan media sosial. Pada skala FoMO, ditemukan sebanyak $36(10,5 \%)$ dari 343 subjek mengalami FoMO dengan tingkat tinggi. Berdasarkan hasil penelitian ditemukan umumnya remaja merasa kecewa jika melewatkan kesempatan untuk berkumpul dengan teman-temannya, apalagi jika dirinya tidak diajak dalam pertemuan tersebut. Pada skala social media engagement, ditemukan sebanyak 75 (21,9\%) dari 343 subjek mengalami social media engagement dengan tingkat tinggi. Berdasarkan skala tersebut, diketahui hampir seluruh remaja menggunakan media sosial setiap hari saat 15 menit sebelum tidur dan 15 menit setelah bangun tidur.

Tabel 2-4 memaparkan deskripsi setiap tingkatan kategori pada masing-masing variabel.

Tabel 2. Kategorisasi Variabel Kecanduan Media Sosial

\begin{tabular}{crrr}
\hline Skor & Kategorisasi & \multicolumn{1}{c}{ Jumlah } & Persentase (\%) \\
\hline $0-4$ & Tidak Kecanduan & 245 & $71,4 \%$ \\
$5-9$ & Kecanduan & 98 & $28,6 \%$ \\
\hline
\end{tabular}

Tabel 3. Kategorisasi Variabel Fear of Missing Out

\begin{tabular}{clrr}
\hline $\begin{array}{c}\text { Rumus } \\
\text { Kategorisasi } \\
\text { Jenjang }\end{array}$ & Kategorisasi & Jumlah & $\begin{array}{c}\text { Persentase } \\
\mathbf{( \% )}\end{array}$ \\
\hline $\mathrm{X}<21$ & Rendah & 140 & $40,8 \%$ \\
$21 \leq \mathrm{X}<33$ & Sedang & 167 & $48,7 \%$ \\
$\mathrm{X} \geq 33$ & Tinggi & 36 & $10,5 \%$ \\
\hline
\end{tabular}

Tabel 4. Tingkatan Kategori pada Variabel Social Media

\begin{tabular}{|c|l|r|r|}
\hline $\begin{array}{c}\text { Rumus } \\
\text { Kategorisasi } \\
\text { Jenjang }\end{array}$ & Kategorisasi & Jumlah & \multicolumn{1}{c|}{$\begin{array}{c}\text { Persentase } \\
(\%)\end{array}$} \\
\hline$X<5,56$ & Rendah & 49 & $14,3 \%$ \\
\hline $20,56 \geq X \geq 5,56$ & $\begin{array}{l}\text { Tidak } \\
\text { terkategorisasi }\end{array}$ & 212 & $61,8 \%$ \\
\hline$X>20,56$ & Tinggi & 82 & $23,9 \%$ \\
\hline
\end{tabular}

Hasil analisis regresi berganda (multiple regression) dengan metode bootstraping dilakukan untuk mengukur masing-masing komponen dari model mediasi yang diajukan. Pertama, ditemukan bahwa FoMO memiliki hubungan positif terhadap kecanduan media sosial ( $\mathrm{B}=0,10$; $\mathrm{t}(343) 7,12$; $\mathrm{p}<0,001)$, hal yang sama ditemukan bahwa FoMO berhubungan positif dengan social media engagement $(\mathrm{B}=0,24 ; \mathrm{t}(343) 3,32 ; \mathrm{p}<0,05)$. Terakhir, hasil menunjukkan bahwa social media engagement 
(mediator) berhubungan positif dengan kecanduan media sosial ( $\mathrm{B}=0,07$; $\mathrm{t}$ (343) 8,28; $\mathrm{p}<0,001)$. Penelitian ini menggunakan interval kepercayaan $95 \%$ pada 5000 sampel (Preacher \& Hayes, 2008). Hasil dari analisis mediasi menunjukkan bahwa social media engagement berperan secara positif sebagai mediator terhadap hubungan FoMO dengan kecanduan media sosial $(\mathrm{B}=0,10, \mathrm{Cl}=0,01-0,03)$. Karena nol tidak termasuk dalam rentang interval kepercayaan 95\%, maka dapat ditarik kesimpulan bahwa terdapat efek tidak langsung yang signifikan antara FoMO terhadap kecanduan media sosial melalui social media engagement. Hayes (2013) mengatakan jika ren-tang antara BootLLCI dan BootULCI tidak mencakup nilai nol (0) maka estimasi signifikan dan terjadi efek mediasi. Sebagai tambahan, hasil menunjukkan bahwa hubungan langsung antara FoMO terhadap kecanduan media sosial tetap signifikan ( $\mathrm{B}=0,08 ; \mathrm{t}$ (343) 6,$20 ; \mathrm{p}<0,001$ ) ketika social media engagement dikontrol sehingga termasuk kepada mediasi parsial (Rucker, Preacher, Tormala, \& Petty, 2011).

Hal ini menunjukkan bahwa hipotesis penelitian diterima yaitu terdapat hubungan antara FoMO dengan kecanduan media sosial yang dimediasi oleh social media engagement pada remaja di Kota Banda Aceh. Hasil penelitian ini senada dengan hasil penelitian Wegmann, dkk., (2017) yang menemukan bahwa individu yang mengalami FoMO memiliki dorongan untuk terus menerus menggunakan media sosial sehingga intensitas penggunaan media sosial menjadi meningkat dan dapat mengarah kepada kecanduan media sosial. Individu yang mengalami FoMO memiliki keinginan untuk terhubung secara sosial dan terdorong untuk mengetahui apa saja yang dilakukan oleh individu lain (Fuster, dkk., 2017). Adanya keinginan untuk terus menjadi bagian dari pengalaman yang mengesankan membuat intensitas individu dalam menggunakan media sosial meningkat sehingga menyebabkan kecanduan media sosial (Abel, Buff, \& Burr, 2016).

Menurut Shapiro dan Margolin (2014), remaja yang mengalami FoMO memiliki ketertarikan untuk menggunakan media sosial sehingga remaja dapat tetap terhubung secara terus menerus dengan teman-temannya. Lebih lanjut, Fuster, dkk., (2017) menyatakan bahwa individu yang mengalami FoMO dengan tingkat tinggi terdorong untuk memeriksa media sosial lebih sering agar dapat mengikuti rencana dan kegiatan bersama individu lain.

Hadirnya media sosial sebagai media untuk dapat terhubung, berbagi, dan memiliki pengalaman yang mengesankan dengan individu lain. Oleh karena itu, dampak yang mungkin dimunculkan dari perilaku individu yang mengalami FoMO adalah meningkatnya penggunaan media sosial. Hal ini diungkapkan oleh Salehan dan Negahban (2013), adanya kesempatan untuk tetap terhubung melalui media sosial kapan pun dan dimana pun dapat meningkatkan social media engagement. Individu yang mengalami social media engagement yang tinggi dapat dilihat melalui tingginya jumlah aktivitas pada penggunaan media sosial (McCay-Peet \& Quan-Haase, 2016).

Berdasarkan penjelasan di atas diketahui bahwa akibat yang dimunculkan dari FoMO dapat mengarahkan individu kepada social media engagement yang tinggi. Hal ini terlihat dari karakteristik individu yang mengalami FoMO, yaitu memiliki dorongan untuk terus mengetahui dan terlibat dengan hal yang orang lain ketahui dan lakukan melalui media sosial. Pemenuhan akan dorongan tersebut melalui media sosial menyebabkan intensitas yang tinggi dalam penggunaan media sosial yang disebut dengan social media engagement.

Intensitas yang tinggi dalam menggunakan media sosial mengarah kepada salah satu simtom yang ada pada kecanduan media sosial, yaitu tolerance. Eijnden, dkk., (2016) menjelaskan bahwa tolerance ditandai dengan adanya peningkatan jumlah waktu yang dihabiskan dalam menggunakan media sosial. Oleh karena itu, munculnya salah satu simtom tersebut dapat mengarahkan remaja kepada perilaku kecanduan media sosial.

Berdasarkan pemaparan di atas, hubungan tidak langsung dapat terjadi antara FoMO dengan kecanduan media sosial akibat hadirnya social media engagement. Hal ini menunjukkan adanya dorongan untuk mengatasi kekhawatiran akan kehilangan pengalaman yang menyenangkan melalui media sosial terlebih dahulu menyebabkan tingginya aktivitas penggunaan media sosial kemudian mengarah kepada perilaku kecanduan media sosial.

Hubungan antara FoMO dengan kecanduan media sosial juga terjadi secara langsung. Abel, dkk., (2016) menyatakan bahwa tersedianya informasi dengan konten dan waktu yang tidak terbatas pada media sosial memungkinkan individu yang mengalami FoMO dapat terus mempertahankan keterlibatan dirinya di lingkungan sosial. Penggunaan media sosial secara terus menerus menyebabkan kecanduan media sosial (Kuss \& Griffiths, 2011). Oleh karena itu, hasil penelitian menunjukkan terdapat hubungan langsung antara FoMO dengan kecanduan media sosial serta hubungan tidak langsung antara FoMO dengan kecanduan media sosial yang dimediasi oleh social media engagement.

Peneliti menyadari terdapat beberapa kelemahan, diantaranya yaitu konsep pengkajian teori tidak terungkap secara mendalam karena menggunakan brief scale pada masing-masing variabel. Selain itu, penelitian ini berbentuk kuantitatif sehingga tidak dapat melihat interaksi lebih dalam antar variabel.

\section{SIMPULAN}

Penelitian ini menemukan bahwa pada remaja di Banda Aceh, FoMO berpengaruh terhadap kecanduan media sosial, baik secara langsung maupun tidak langsung, yaitu lewat mediator social media engage- 
ment. Hubungan langsung dilakukan dengan menguji variabel FoMO dengan kecanduan media sosial. Hasil menunjukkan bahwa hubungan langsung antara FoMO dengan kecanduan media sosial signifikan. Selanjutnya, hubungan tidak langsung dilakukan dengan menguji variabel FoMO terhadap kecanduan media sosial melalui social media engagement. Hasil menunjukkan bahwa social media engagement berperan secara positif sebagai mediator terhadap hubungan FoMO dengan kecanduan media sosial. Adanya hubungan yang signifikan antara FoMO dengan kecanduan media sosial saat social media engagement dikontrol menunjukkan adanya peran mediasi parsial. Hubungan tidak langsung menunjukkan bahwa adanya FoMO di dalam diri individu terlebih dahulu menyebabkan tingginya aktivitas penggunaan media sosial kemudian mengarah kepada perilaku kecanduan media sosial. Sedangkan FoMO juga dapat menyebabkan kecanduan media secara langsung karena terus mempertahankan keterlibatan dirinya secara terus menerus di media sosial sehingga menyebabkan kecanduan media sosial.

Peneliti selanjutnya yang ingin melakukan penelitian dengan variabel yang sama dapat meneliti dengan menggunakan metode kualitatif melalui observasi dan wawancara untuk memperdalam hasil penelitian, terutama mengenai alasan remaja yang mendorong dirinya terhadap penggunaan media sosial sehingga mengalami kecanduan. Selain itu, peneliti selanjutnya dapat memperdalam aspek teori yang digunakan dengan memperluas usia subjek penelitian. Terakhir, variabel kecanduan media sosial juga dapat dikaji dengan beberapa variabel psikologi lain yang tidak dijelaskan dalam penelitian ini.

\section{DAFTAR PUSTAKA}

Abel, J. P., Buff., C. L., \& Burr, S. A. (2016). Social media and the fear of missing out: scale development and assessment. Journal of Business \& Economic Research, 14(1), 33-44

Al-Menayes, J. (2016). The fear of missing outscale: validation of the Arabic version and correlation with media sosial addiction. International Journal of Applied Psychology, 6(2), 41-46. doi: 10.5923/j. ijap.20160602.04

Ang, C. (2017). Internet habit strength and online communication: exploring gender differences. Computers in Human Behavior, 66, 1-6. doi: 10.1016/j.chb.2016.09.028.

Asosiasi Penyelenggara Jasa Internet Indonesia (APJII). (2014). Profil Pengguna Internet Indonesia 2014. Jakarta: Penerbit Pusat Kajian Komunikasi Universitas Indonesia

Asosiasi Penyelenggara Jasa Internet Indonesia (APJII). (2016). Infografis Penetrasi dan Perilaku Pengguna
Internet Indonesia 2016. Jakarta: Penerbit Polling Indonesia

Badan Pusat Statistik Kota Banda Aceh. (2018). Kota Banda Aceh dalam Angka. Banda Aceh: Badan Pusat Statistik Kota Banda Aceh

Baron, R. M. \& Kenny, D. A. 1986. The ModeratorMediator Variable Distinctionin Social Psychological Research: Conceptual, Strategic, and StatisticalConsiderations. Journal of Personality and Social Psychology, 51(6), 1173-1182

Brand, M., Laier, C., \& Young, K. S. (2014). Internet addiction: coping styles, expectancies, and treatment implications. Frontiers in Psychology, 5. doi: 10.3389/fpsyg.2014.01256

Choi, S.W., Kim, D.J., Choi, J.S., Ahn, H., Choi, E.J., Song, W.Y., Kim, S., \& Youn, H. (2015). Comparison of risk and protective factors associated with smartphone addiction and Internet addiction. Journal of Behavioral Addictions, 4(4), 308-314. doi: 10.1556/2006.4.2015.043

Common Sense Media. (2016). Dealing with devices: the parent-teen dynamic, are we addicted?.Artikel Online. Diakses pada 3 Mei 2018 melalui https:// www.commonsensemedia.org/technologyaddiction-concern-controversy-and-findingbalance-infographic

Deci, E. L., \& Ryan, R. M. (2008). Self-determination theory: a macrotheory of human motivation, development, and health. Canadian Psychology, 49(3), 182-185

Eijnden, R. J. J. M. V. D., Lemmens, J. S., \& Valkenburg, P. M. (2016). The media sosial disorder scale. Computers in Human Behavior. 61, 478-487. doi: 10.1016/j.chb.2016.03.038

Ellison, N. B., Steinfield, C., \& Lampe, C. (2007). The benefits of Facebook "friends" social capital and college students' use of online social network sites. Journal of Computer-Mediated Communication, 12, 1143-1168. doi: 10.1111/j.10836101.2007.00367.x

Fuster, H., Chamarro, A., \& Oberst, U. (2017). Fear of missing out, online social networking and mobile phone addiction: a latent profile approach. Aloma, 35(1), 23-30, ISSN: 1138-3194

Hayes, A. F. (2013). Introduction to mediation, moderation, and conditional process analysis. New York: Guilford Press.

Hurlock, E. B. (2009). PsikologiPerkembangan: Suatu Pendekatan Sepanjang Rentang Kehidupan. Jakarta: Penerbit Erlangga

Kirik, A. M., Arslan, A., Cetinkaya, A., \& Gul, M. (2015). A quantitative research on the level of media 
sosial addiction among young people in turkey. International Journal of Science Culture and Sport, 3(3), 108-122. doi: 10.14486/IntJSC444

Kuss, D. J., \& Griffiths, M. D. Social networking sites and addiction: ten lessons learned. International Journal of Environmental Research and Public Health, 14(311), 1-17. doi:10.3390/ijerph14030311

Lenhart, A., Ling, R., Campbell, S., \& Purcell, K. (2010). Teens and Mobile Phones. Washington, DC: Pew Internet \& American Life Project

Long, J. H \& Chen, G. (2007). The impact of internet usage on adolescent self-identity development. China Media Research, 3(1), 99-109

McCay-Peet, L., \& Quan-Haase, A. (2016). A model of social media engagement: user profiles, gratifications, and experiences. Information \& Media Studies. doi: 10.1007/978-3-319-274461_9

Oberst, U., Wegmann, E., Stodt, B., Brand, M., \& Chamarro, A. (2017). Negative consequences from heavy social networking in adolescents: The mediating role of fear of missing out. Journal of Adolescence, 55, 51-60. doi: dx.doi.org/10.1016/j

Oshima, N., Nishida, A., Shimodera, S., Tochigi, M., Ando, S., Yamasaki, S., Okazaki, Y., \& Sasaki, T. (2012). The suicidal feelings, self-injury, and mobile phone use after lights out in adolescents. Journal of Pediatric Psychology, 37, 1023-1030. doi: 10.1093/jpepsy/jss072

O’Keeffe, G. S., Clarke-Pearson, K., 2011. Clinical Report - The impact of social media on children, adolescents and families. American Academy of Pediatrics. 800-804

Preacher, K. J., \& Hayes, A. F. (2008). Asymptotic and resampling strategies for assessing and comparing indirect effects in multiple mediator models. Behavior Research Methods, 40, 879-891.

Przybylski, A., K., Murayama, K., Haan, C. R., \& Gladwell, V. (2013). Motivational, emotional, and behavioral correlates of fear of missing out. Computer in Human Behavior, 29, 1841-1848. doi: 10.1016/j.chb.2013.02.014

Rucker, D. D., Preacher, K. J., Tormala, Z. L., \& Petty, R. E. (2011). Mediation Analysis in Social Psychology: Current Practices and New Recommendations. Social and Personality Psychology Compass, 359371. doi: 10.1111/j.1751-9004.2011.00355.x
Salehan, M., \& Negahban, A. (2013). Social networking on smartphones: when mobile phones become addictive. Computers in Human Behavior, 29(6), 2632-2639. doi: 10.1016/j.chb.2013.07.003

Saphiro, L. A. S., \& Margolin, G. (2014). Growing up wired: social networking sites and adolescent psychosocial development. Clinical Child and Family Psychology Review, 17(1), 1-18. doi: 10.1007/s10567-013-0135-1

Siddiqui, S., \& Singh, T. (2016). Media sosial its impact with positive and negative aspects. International Journal of Computer Applications Technology and Research, 5(20), 71 - 75. ISSN:- 2319-8656

Song, X., Zhang, X., Zhao, Y., \& Song, S. (2017). Fearing of missing out (FoMO) in mobile social media environment: conceptual development and measurement scale. iConference 2017 Proceedings, 733-738. doi: 10.9776/17330

Sugiharto, B. A. (2016). Pengguna internet di Indonesia didominasi anak muda. CNN Indonesia. Diakses pada 2 Maret 2018 melalui https://www.cnn indonesia.com/teknologi/20161024161722-185167570 /pengguna-internet-di-indonesiadidominasi-anak-muda

Tim PKM Sosial Humaniora. (2016). 83 persen remaja tidak bisa lepas dari media sosial barang sehari pun. UNAIR News. Diakses pada 2 Maret 2018 melalui http://news.unair.ac.id/2016/06/01/83-persenremaja-tidak-bisa-lepas-dari-media-sosial-barangsehari-pun/

Turel, O., \& Serenko, A. (2012). The benefits and dangers of enjoyment with social networking websites. Europian Journal of Information Systems, 21. ISSN: 512-528

Van den Bulck, J., \& Eggermont, S. (2006). Media use as a reason for meal skipping and fast eating in secondary school children. Journal of Human Nutrition and Dietetics, 19, 91-100. doi: 10.1111/j.1365-277X.2006.00683.X

We are Social. (2015). Southeast Asia digital in 2015. Artikel online. Diakses pada tanggal 22 September 2017 melalui https:/wearesocial.com/specialreports/digital-southeast-asia-2015

Wegmann, E., Oberst, U., Stodt, B., \& Brand, M. (2017). Online-specific fear of missing outand internet-use expectancies contribute to symptoms of internetcommunication disorder. Addictive Behavior Reports, 5, 33-42 